\title{
The Chinese Economic Pivot in Central Asia and Its Implications for the Post-Karimov Re-emergence of Uzbekistan
}

\begin{abstract}
By focusing on the impact of Chinese engagement in Uzbekistan, this article promotes an understanding of the motivations of Central Asian states such as Uzbekistan in strategically engaging China. Although China's Belt and Road Initiative has received wide coverage, few details of other Chinese projects and their impacts have been analyzed. The article aims to fill in this gap by outlining the latest project details of Chinese engagement and their impact in this region.
\end{abstract}

KEYWORDS: Silk Road, Central Asia, Uzbekistan, Belt and Road Initiative

\section{INTRODUCTION}

The strengthening of Chinese influence in Central Asia (CA) has been a result of an overall increase in China's global influence. Indeed, the patterns of Chinese economic and political expansion in CA are not much different from that in other parts of the world. CA represents an area of vital interest for China for various reasons, including security concerns (such as separatism, terrorism and extremism); economic potential (CA is an energy-resource-rich area with a vast market for Chinese goods); political importance (balancing the presence of other powers such as Russia and the Afghanistan-invested US); and infrastructure potential (CA could become a transportation hub for Eurasia). In this sense, the motivations behind the Chinese presence in this region are clearly outlined in Chinese official discourse as well as in the

Timur Dadabaev is an Associate Professor and the Director of the Special Program in Japanese and Eurasian Studies in the Graduate School of Humanities and Social Sciences, University of Tsukuba, Japan. His latest monographs are Identity and Memory in Post-Soviet Central Asia: Uzbekistan's Soviet Past (Routledge, 2015) and Japan in Central Asia: Strategies, Initiatives, and Neighboring Powers (Palgrave Macmillan, 2016). This article was supported by the Ministry of Education, Culture, Sports, Science and Technology of Japan, "Comparative Analysis of Japanese and Chinese Foreign Policies in Central Asia," under grant I5Kor862. Email: <dadabaev.timur.gm@u.tsukuba.ac.jp>.

Asian Survey, Vol. 58, Number 4, pp. 747-769. ISSN ooo4-4687, electronic ISSN I533-838X. @ 2018 by The Regents of the University of California. All rights reserved. Please direct all requests for permission to photocopy or reproduce article content through the University of California Press's Reprints and Permissions web page, http://www.ucpress.edu/journals.php?p=reprints. DOI: https://doi.org/Io.I525/ AS.2018.58.4.747. 
analyses of academicians. ${ }^{1}$ However, in regard to the interests and motivations of CA states, the coverage is mainly limited to wishing to join the bandwagon. The general picture of CA states is usually drawn from the real or imagined attempts of these states to balance the powers of China, Russia, and the US (and other states); new Great Game rhetoric; or a pure utilitarian attitude toward China's vast financial resources and market for energy resources. ${ }^{2}$ While Chinese motivations for engaging in CA are fairly well covered in the literature, few studies analyze how Chinese economic expansion fits the domestic plans and priorities of Central Asian states. ${ }^{3}$ And few studies focus on the role and place of China (both its government and its corporate community) in the modernization of these societies. There is also little attempt to describe not only the outcome of Chinese-Central Asian cooperation but also the process of agenda-setting for cooperation and how this agenda is then implemented. ${ }^{4}$ Chinese and Central Asian policymakers often note that their cooperation has mutual benefits and that all sides involved are in a position to set and redefine the agenda for cooperation. However, in many cases, the commentaries on such cooperation schemes tend to emphasize the economic strength of the Chinese and their persistence in lobbying for economic benefits in CA, while Central Asian states are depicted as mere consumers of the Chinese economic, political, and social agenda. ${ }^{5}$

I. See e.g. "Uzbekistan I Kitaj gotovy prodvigat stroitel'stvo novogo Evrazijskogo kontinental'nogo mosta" [Uzbekistan and China are ready to promote construction of new Eurasian land bridge], interview with Ambassador of China to Uzbekistan Sun Lijie, Podrobno, June 2, 20I7; Oybek Madiyev, "Why Have China and Russia Become Uzbekistan's Biggest Energy Partners? Exploring the Role of Exogenous and Endogenous Factors," Cambridge Journal of Eurasian Studies I, March I5, 20I7, <https://doi.org/I0.2226I/QYJ7IT>.

2. For a narrative of Chinese interests in CA, see Andrew Scobell, Ely Ratner, and Michael Beckley, China's Strategy toward South and Central Asia: An Empty Fortress (Santa Monica, CA: RAND Project Air Force, 20I4): 27-48, <https://www.rand.org/pubs/research_reports/RR525. readonline.html>, accessed September 23, 2017.

3. On the complementarity of Chinese Belt and Road and Kazakh domestic Nurly Zhol policy, see e.g. Nargis Kassenova, "China’s Silk Road and Kazakhstan's Bright Path: Linking Dreams of Prosperity,” Ponars Eurasia, 2017, <http://www.ponarseurasia.org/article/china's-silk-road-andkazakhstan's-bright-path-linking-dreams-prosperity>, accessed October 2, 2017.

4. On Chinese domestic agenda-setting in foreign policy, see Linda Jakobson and Ryan Manuel, "How Are Foreign Policy Decisions Made in China?" Asia \& the Pacific Policy Studies 3 (2016): IOI-IO, doi:IO.IOO2/app5.I2I.

5. On increasing Chinese global assertiveness, see Nien-Chung Chang Lao, "The Sources of China's Assertiveness: The System, Domestic Politics or Leadership Preferences?" International Affairs 92 (2016): 817-33, doi:Io.III//468-2346.I2655. 
Uzbekistan's relations with China are of special importance in this regard. As is frequently noted by scholars and practitioners, Uzbekistan is centrally located, resource-rich (especially in rare metals and natural gas), and the most populous country in CA, with a population almost equal to the population of all other Central Asian states combined. Such advantageous central, resource, and demographic positioning alone suggests that any instability in this country may raise questions about the stability of CA in general, and have a critical effect on Chinese plans for the Belt and Road Initiative and other schemes in this region. ${ }^{6}$

Above all, what attracted region watchers and experts to the foreign policy of Uzbekistan recently was the long-anticipated change of power after the death of Islam Karimov, the first president of Uzbekistan, in September 2or6, and the appointment of Shavkat Mirziyoyev as interim president, and then his election to the presidency in December 2016. ${ }^{7}$ While Karimov was famous for balancing the influence of all regional and non-regional states in his quest to solidify his hold on economic and political power, the change of leadership signified an opening up of the country to new engagement with the international community. At the same time, this opening up has raised many questions about the direction of Uzbekistan's foreign policy in the postKarimov era. Some scholars predict a policy of distance from all powerful states, while others argue that Uzbekistan will follow a pro-Russian or, alternatively, a pro-Chinese foreign policy. ${ }^{8}$

6. National Development and Reform Commission, "Vision and Actions on Jointly Building Silk Road Economic Belt and 2rst-Century Maritime Silk Road," March 30, 2015, Ministry of Foreign Affairs and Ministry of Commerce, PRC; Office of the Leading Group for the Belt and Road Initiative, Building the Belt and Road: Concept, Practice and China's Contribution (Beijing: Foreign Languages Press, 2017), <https://eng.yidaiyilu.gov.cn/wcm.files/upload/CMSydylyw/ 201705/201705110537027.pdf>, accessed March I2, 2018; Timur Dadabaev, "Silk Road as Foreign Policy Discourse: The Construction of Chinese, Japanese and Korean Engagement Strategies in Central Asia," Journal of Eurasian Studies 9 (2018): 30-4I.

7. Timur Dadabaev, "The Constructivist Logic of Uzbekistan's Foreign Policy in the Karimov Era and Beyond," Uzbekistan Forum and Virtual Special Issue, Central Asian Survey (September 20I6): I-4, <https://www.tandf.co.uk//journals/pdf/8_Dadabaev_final\%20220916.pdf>, accessed June 9, 20I8; Timur Dadabaev, "Uzbekistan as Central Asian Game Changer? Uzbekistan's Foreign Policy Construction in the Post-Karimov Era," Asian Journal of Comparative Politics, May I8, 20I8, $<$ doi.org/IO.II77/205789III8775289>.

8. Samuel Ramani, "Are Uzbekistan's Ties with China Headed For a Change?” Radio Free Europe / Radio Liberty, September I2, 2016, <https://www.rferl.org/a/qishloq-ovozi-uzbekistanchina-relations-change-karimov-death/27982369.html>, accessed September 23, 2017. 
Considering these issues, this paper raises several questions: How has the change of leadership influenced the change in Uzbekistan's foreign policy behavior in general and specifically in its policy toward China? What areas does Uzbekistan prioritize in engaging China? What are the institutions and motivations for setting up the agenda for this cooperation?

By providing answers to these questions, this article first contributes to the understanding of the impact of Uzbekistan's change of power and its evolving relations with China. Second, I explain the motivations of strategically important (in terms of economy, demography, and political capability) Central Asian states such as Uzbekistan in engaging China. Third, I provide details of Chinese engagement in this region by outlining the latest project details. Although China's Belt and Road Initiative has received wide coverage, few details of the Chinese projects that constitute Belt and Road engagement (aside from infrastructure) and their impacts have been analyzed. ${ }^{9}$

To answer the questions listed above, I first analyze two major documents adopted after the change of leadership in Uzbekistan: the January 2017 "Strategy for Further Development" (covering 20I7-2I) and the January 2018 foreign policy speech of President Mirziyoyev. ${ }^{10}$ Both documents define priorities in Uzbekistan's development and the regional and non-regional states that Uzbekistan considers most important. Through this analysis, this paper aims to identify the role of China in Uzbekistan's emerging foreign policy in the post-Karimov era. Next, I explain how cooperation between Uzbek and Chinese policymakers in the areas of Uzbek concern is made possible by describing how the intergovernmental bureaucracy works and the norms and practices of bureaucracy shared by both countries. The analysis then outlines several areas of cooperation, with a description of the agreements achieved during the visit of President Mirziyoyev to China in May 2017, and how these agreements have been implemented. This part of the paper aims to demonstrate that the agreements signed in Beijing focus almost exclusively on areas coinciding with those selected for the national

9. Sarah Lain, "Russia and China: Cooperation and Competition in Central Asia," in Tiang Boon Hoo (ed.), Chinese Foreign Policy under Xi (London: Routledge, 20I7): 74-95; Timur Dadabaev, "Engagement and Contestation: The Entangled Imagery of the Silk Road," Cambridge Journal of Eurasian Studies 20I8, 2: \#Q4GIV6, <https://doi.org/Io.2226I/CJES.Q4GIV6>.

Io. Shavkat Mirziyoyev, "Effektivnaya Venshnyaya Politika: Vazhneishee Uslovie Uspeshnoy Realizatsii Vneshnei Politiki" [Effective foreign policy: the most important condition of the successful foreign policy], January, II, 20I8, <http://press.natlib.uz/ru/edition/download?id=4558> accessed June 9, 2018. 
development strategy of Uzbekistan. Although there are very important security interests shared by China and Uzbekistan, due to space limitations and the large number of studies addressing this topic, this paper does not describe the history of the Shanghai Cooperation Organization's relations with Uzbekistan or the history of diplomatic relations that can be found elsewhere. ${ }^{11}$ It focuses almost exclusively on explaining the development of various areas of cooperation under the new leadership from September 2016, to highlight the latest trends and developments in relations between the two countries.

Through all of its sections, this article aims to deliver the message that Uzbekistan is engaging China in a new domestic and international environment of opening up after decades of Karimov's rule. In particular, Mirziyoyev aims to change the strategy of Uzbekistan from reactionary (mainly reacting to changes in the international environment) toward proactive. In such a shift, China (in economic terms) is attributed an important role as a source of technology transfer, an investor, and a market for Uzbek resources and goods. Russia, in turn, represents a vast market for agricultural products and certain industrial goods (cars, certain electronics), as well as a labor market. By modernizing its technological assets and the industrial sector of its economy, Uzbekistan aims to create an economic structure that will allow it to reduce the share of imports from other countries and, importantly, increase the share of exports, not only to China but also to other Central Asian states. Uzbekistan aims to take advantage of its abundant human resources and cheap labor to create an export-oriented economy with respect to neighboring countries that suffer from either energy-resource-centered economic development or a lack of diversified manufacturing capacity. As described below, Chinese technology transfer might not offer the most advanced technology, but it is sufficient for Uzbekistan's goal of creating an export-oriented industrial base. In cases where more-advanced technology is required, Uzbekistan chooses the Republic of Korea or Japan for technology transfer. ${ }^{12}$ In this

II. See e.g. Yuan Jing-Dong, "China's Role in Establishing and Building the Shanghai Cooperation Organization (SCO)," Journal of Contemporary China 19:67 (2010): 855-69; Timur Dadabaev, "Shanghai Cooperation Organization (SCO) Regional Identity Formation from the Perspective of Central Asian States," Journal of Contemporary China 23:85 (2014): IO2-I8.

I2. In particular, the Ministry of Agriculture and Water Management of Uzbekistan is cooperating with Japan on increasing the efficiency of water consumption at the consumer level. The ministry also announced in 2017 that Uzbekistan is interested in importing technologies using hydroponic growing methods for agricultural products from Japan, South Korea, and Iran ("RUz Budet Vyraschivat Frukty 
sense, the evolving foreign policy of Uzbekistan displays flexibility in choosing international partners depending on the country's need to support economic restructuring.

\section{NATIONAL DEVELOPMENT STRATEGY OF UZBEKISTAN AND THE ROLE OF CHINA}

President Karimov's foreign policy has been described in various ways. In the early I990s, Uzbek foreign policy was regarded by many as emphasizing the importance of Russia and Turkey. ${ }^{13}$ The expert community assumed that this trend was later reconsidered in light of perceived threats from Turkey ${ }^{14}$ and a lack of commitment from Russia. ${ }^{15}$ Others saw signs of Uzbekistan's proWestern policy in the late I990s and early 2000s. However, US criticism of Karimov's handling of the Andijan events of 2005 and the wave of color revolutions welcomed by the US and Europe pushed Uzbekistan to the offensive. ${ }^{16}$ Uzbekistan has since been considered to be building closer economic and political ties with Russia, China, and South Korea, while treating US and European initiatives as threatening to its sovereignty. These drastic shifts were described as reactionary and opportunistic. With intensification of the Russian Eurasian initiative and the Chinese Belt and Road Initiative in the later 200os, experts described Uzbekistan as moving to balance Russian and Chinese influences by gradually improving its US ties to diversify its external partners.

When Mirziyoyev became president, Russian and other media sources speculated that Uzbekistan would move closer to Russia because of his

Kruglyi God," Sputnik, September 6, 2017, <http://ru.sputniknews-uz.com/economy/20170906/ 6236626/uzbekistan-selhozkulturi.html>, accessed September 23, 2017). Hydroponic growing uses mineral nutrient solutions to feed the plants in water, without soil. This technology is important for Uzbekistan, given the water deficiencies and soil corrosion in certain areas of the country. It could also allow Uzbekistan to produce agricultural products throughout the year. Finally, India and Pakistan have been given roles as trading and humanitarian exchange partners.

13. Bernardo Teles Fazendeiro, Uzbekistan's Foreign Policy: The Struggle for Recognition and SelfReliance under Karimov (Oxon: Routledge, 20I7).

I4. Perceived threats from Turkey included support of the anti-Karimov opposition in exile and influence of Islamic radicals from Turkey on internal politics of Uzbekistan.

I5. Timur Dadabaev, Towards Central Asian Regional Integration: A Scheme for Transitional States (Tokyo: Akashi, 2004).

16. The Andijan events refers to the May 13, 2005, clash between the Uzbek Interior Ministry and National Security Service and a crowd of protesters in Andijan (who the government claimed were a Islamic radical group called Akromiya), in which a great number of civilian casualties were reported. 
perceived close personal ties to Russian elites. ${ }^{17}$ However, Uzbekistan has since declared several principles for new foreign policy behavior that discursively adhere to the old policy but, in practice, demonstrate a drastic departure from the behavior of Uzbekistan under Karimov. First, Mirziyoyev chose a foreign policy direction centered on non-alignment with military and political blocs and non-intervention in the affairs of neighboring states. ${ }^{18}$ This principle was reconfirmed in his first address to the joint session of the chambers of parliament in September 20I6. Second, Uzbekistan announced that its main priorities lie in improving and maintaining its relations with neighboring Central Asian states. This principle had consistently been stated in previous years, but there was little evidence of its being operationalized. Mirziyoyev demonstrated his commitment through II visits, two working visits, and I5 phone calls with presidents of neighboring countries in his first year in office. This produced outcomes that had been difficult to achieve over the 25 years of independence of these states. Uzbekistan managed to find compromises with Kyrgyzstan over border- and water-related problems; with Tajikistan over transportation networks, air communications, and cultural exchange; and with Kazakhstan over the opening of Uzbek market for imports and promoting Uzbek exports and eventual intensification of trade. Uzbekistan also announced that it aims to develop its economic relations to export domestically produced goods to neighboring countries and even to establish joint manufacturing plants for Uzbek producers in other Central Asian states, such as Kazakhstan. Therefore, for Uzbekistan, CA has become an area of not only cultural exchange but also extended economic activity. Importantly, Uzbekistan refuses to prioritize any particular country in CA (for instance Kazakhstan), suggesting that it wants to build equally important relations with all Central Asian states. ${ }^{19}$

I7. Asatryan, Zabrodin, and Sozaev-Gur'ev, "V Moskve Zhdut Uzbekskogo Lidera i Raschityvayut na Konstruktivnyi Dialog" [Moscow expects Uzbek leader and hopes for constructive dialogue], Izvestia, December 7, 2016, <http://iz.ru/news/649838>, accessed April 2, 2017.

I8. See also Falyahov, "Uzbekistan ne Speshit v Evrazijskij Soyuz" [Uzbekistan does not rush into Eurasian Union], Gazeta, April 5, 2017, <http://www.gazeta.ru/business/2017/04/o5/10612535. shtml>, accessed September 23, 2017.

19. "Glava MID Uzbekistana otvergnul ideyu sozdaniya 'regional'noi osi' Astana-Tashkent" [The head of MFA of Uzbekistan rebuffed the idea of creating 'regional axis' of Astana-Tashkent], Podrobno, September 29, 20I7, <http://podrobno.uz/cat/politic/glava-mid-uzbekistana-otvergnulideyu-sozdaniya-regionalnoy-osi-astana-tashkent/> accessed September 29, 2017. 
TABLE I. Major Export Destinations for Uzbek Goods, 20I6-I7

\begin{tabular}{llc}
\hline Rank & Country & Percentage of Uzbek exports \\
\hline I & Russia & $18 \%$ \\
2 & China & $16 \%$ \\
3 & Turkey & $15.7 \%$ \\
4 & Kazakhstan & $1 \mathrm{I} .5 \%$ \\
5 & Iran & $8 \%$ \\
6 & Afghanistan & $5.8 \%$ \\
7 & Kyrgyzstan & $2.4 \%$ \\
8 & Korea & $2.2 \%$ \\
\hline
\end{tabular}

Note: Excludes energy resources and services. Compiled by the author from interviews with government officials and consultants.

Within this structure, Uzbekistan still needs to develop and diversify its industrial base to modernize its manufacturing capacity and generate varied types of goods of sufficient quality to export to its neighbors. In this regard, as a third principle of Uzbek foreign policy, Mirziyoyev announced that China (along with Russia) is expected to become one of the most important nonregional partners. This announcement was based on previous successful engagements with China (for example, the China-led Shanghai Cooperation Organization and its "Shanghai spirit") as well as on careful calculations of the needs of the Uzbek economy, outlined in the strategy for Uzbek development explained below. Interestingly, Mirziyoyev further suggested Japan and South Korea as important partners in economic cooperation, and as sources of investments and technologies for the Uzbek economy, presumably targeting the areas where Chinese technological advances are not considered sufficiently developed. Currently, China is the second-largest export destination for Uzbekistan (Table I).

Uzbek foreign behavior demonstrates that its motivations in respect to both China and CA are socially constructed and contingent on the history and legacy of previous interactions. Rationalists treat the interests of both Uzbekistan and larger powers such as China as stable (in line with domination and survival rhetoric), and predetermined, but this paper aims to demonstrate that national interests change according to both the interaction and the environment. Therefore, both China and Uzbekistan redefine their 
identities (that is, become who they are) within their interactions, and their interests are defined by these interactions.

Accordingly, at the current stage of its development, Uzbekistan prioritizes $\mathrm{CA}$ as an area of vital importance. At the same time, the discourse of Uzbekistan siding exclusively with Russia, China, or the US in the post-Karimov era was not empirically demonstrated in the first year of Mirziyoyev's presidency. From the perspective of Uzbekistan, many of the projects promoted by the EU, the US, Russia, China, South Korea, and Japan are mutually compatible. In this context, China's role has shifted from being a partner in providing security and fighting terrorism to being the main source of technology and financing for the diversification of Uzbekistan's economy.

In its interactions with foreign partners, Tashkent distinguishes long-term and short-term priorities. The long-term priorities have not radically changed. They are mainly aimed at reducing imports and increasing exportoriented manufacturing. ${ }^{20}$ The areas prioritized by the development strategy mentioned above are rooted in an analysis of the structure of Uzbekistan's GDP. Per the latest economic indicators, the share of industry in GDP is only one-third (33.1\%), with the remaining shares attributed to services (almost half), agriculture, forestry, and fishery (one-fifth). ${ }^{21}$

Therefore, the development strategy for 20I7-2I aims to expand industry and diversify Uzbekistan's economy. Private-sector participation in the production of Uzbekistan's GDP is also very low, especially in industry, forcing the government to take the lead in seeking foreign partners (Figure I).

Therefore, policy supporting the development of export-oriented, small and medium-sized private industrial production plants was announced a couple of decades ago and has been inherited by the current government (Table 2). However, the short-term priorities are defined through various programs that have a timeframe for implementation. Once a specific program is completed, another defines the new short-term priorities of the country.

It would thus be incorrect to assume that Uzbekistan is prepared to accept any agenda set by its counterparts such as China or Russia, as long as this

20. On the logic of Uzbek self-reliance, see Bernardo Teles Fazendeiro, "Uzbekistan's 'Spirit' of Self-Reliance and the Logic of Appropriateness: TAPOich and Interaction with Russia," Central Asian Survey 34:4 (2015): 484-98, doi:Io.1080/02634937.2015.III4780.

21. State Statistics Committee, "Statesticheskoe Obozrenie Uzbekistana" [Statistic review of Uzbekistan], Tashkent, 2017: 4. 
FIGURE I. Share of Small and Medium-Sized Enterprises by Economic Sector, 2016

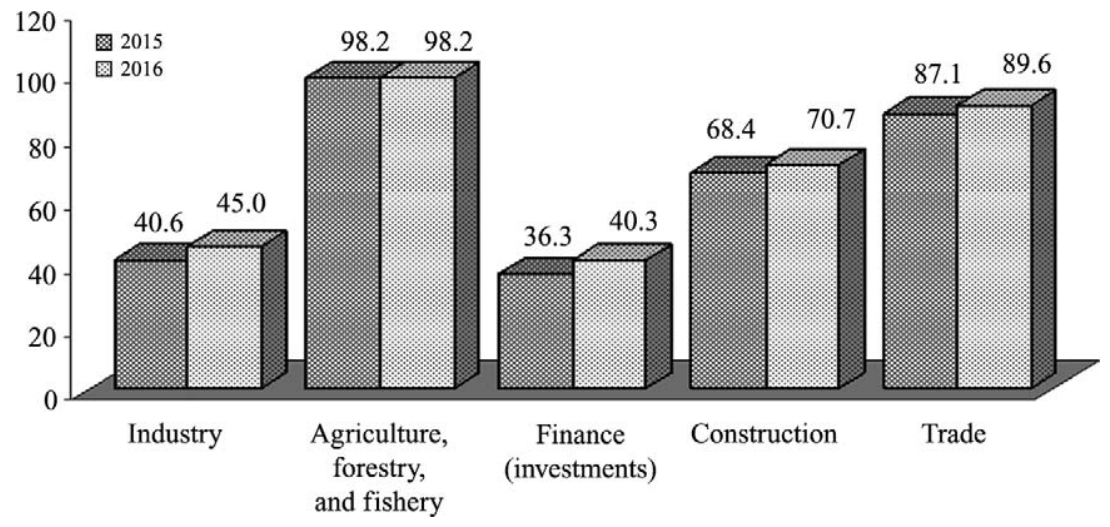

SOURCE: State Statistics Committee of Uzbekistan.

TABLE 2. Share of the private sector in the total volume of produced goods and services, 2016

Industry

Agriculture, forestry, and fishery

Construction

Retail trade turnover

Transportation of goods

Transportation of passengers

Exports

Imports

$$
48.2
$$

IOO

66.2

83.6

63.6

9I.4

3.8

$\mathrm{I} 2.2$

SOURCE: State Statistics Committee of Uzbekistan.

agenda implies investments. As a guideline for a cooperation agenda, the development strategy outlined five areas to be prioritized:

- Improvements to the state public administration system

- Improvements to the judicial system

- Liberalization of the economy

- Development of the social sphere

- Facilitation of security, promotion of interethnic and interreligious accord, and implementation of a balanced, beneficial and constructive foreign policy 
The wide spectrum of reforms required has led Uzbekistan to adopt a stepby-step approach, beginning with improving the system of state operations (streamlining bureaucratic procedures for more efficient and corruption-free operations) and improving the judicial system. In respect to relations with China, "liberalization of the economy" and "implementation of a balanced and beneficial foreign policy" are of special importance. Economic investments that entail technology transfer to establish an export-oriented manufacturing sector in Uzbekistan directly relate to cooperation schemes planned with China. Such reforms are expected to prepare economic conditions in which Chinese (and other) investors will be interested in building plants in Uzbekistan. The liberalization of the currency — which implies elimination of the "black market" rate, unification of governmental and market exchange rates, and guarantees from the government to convert local currency into foreign ones without restrictions-is one of the crucial steps in this direction, as it will allow investors to move capital in and out of country freely.

The last point, regarding foreign policy, includes not only establishing priorities for countries but also drafting action plans and road maps for cooperation with each country considered strategically important. Actions plans for Kazakhstan, Russia, Turkey, and Kyrgyzstan have been signed during Mirziyoyev's visits to these countries and are now being implemented. The action plan and its road map for relations with China was developed and signed during Mirziyoyev's visit in May 2017.

\section{NEGOTIATING STRATEGY AND BARGAINING PLATFORM}

In countries with a limited market economy, the state performs certain functions to guide state and non-state enterprises toward specific areas of development and geographic locations by motivating market actors through economic and administrative measures. In this sense, the government structures in Uzbekistan and China are similar, in that they both strive for a developmental (as opposed to regulatory) function. Governmental ties and communications are crucial in establishing inter-state economic ties between China and Uzbekistan.

On the Chinese side, in the action plan drafted in 2015 by the Ministry of Foreign Affairs, the National Development and Reform Commission, and the Ministry of Commerce, the five policies of policy coordination, connectivity, unimpeded trade, financial cooperation, and people-to-people 
bonds were considered of the highest importance for Chinese penetration in this region. ${ }^{22}$ The same type of commitment has been displayed by the Uzbek governmental bureaucracy, which prepared its own road map emphasizing cooperation at the governmental level to facilitate trade. ${ }^{23}$ In addition, the similarities of governmental structures and style of governance described below have a certain role to play in simplifying cooperation between these two countries. This may be why bilateral negotiations have been more productive than those with free market economies where the government has a limited capacity to influence the behavior of market participants. ${ }^{24}$

The main actors in these negotiations are the Ministry of Foreign Trade, the Chamber of Commerce, and the Agency for Foreign Investments, and these are coordinated by the central apparatus of the Uzbek government. The problems and issues listed in the development strategy serve as guidelines for the government bureaucracy, which then presents proposals to those potential foreign partners (governments) considered the best suited to assist in these tasks. In the case of China, the list is compiled and presented in the Uzbek-Chinese intergovernmental committee for cooperation, co-headed by the Uzbek deputy prime minister and the secretary of the Chinese Communist Party's Political-Judicial Committee. ${ }^{25}$

The work of the intergovernmental committee is divided among several subcommittees, such as the subcommittees on trade and economic relations (coordinated by the Uzbek Ministry of Foreign Trade and the Chinese Ministry of Commerce), cooperation in energy (coordinated by the Uzbek Ministry of the Economy and the PRC National Energy Administration), transportation (coordinated by the Uzbek Ministry of Foreign Trade and the PRC Ministry of Transport), technical and scientific cooperation (coordinated by the Uzbek Committee on Coordination of Science and Technology

22. Sarah Lain, "Russia and China: Cooperation and Competition in Central Asia," in Tiang Boon Hoo (ed.), Chinese Foreign Policy under Xi (London: Routledge, 20I7): 74-95, in particular 77.

23. For instance, Uzbek Foreign Trade and the PRC Ministry of Commerce signed memoranda to facilitate the organization of producer exhibitions in May 2017.

24. For instance, such a cooperation structure was described as impossible in the case of UzbekJapanese cooperation by a Japanese embassy official in a private conversation (September 20I7, Tashkent), due to a regulatory function of the Japanese government which cannot force Japanese corporations into foreign cooperation schemes.

25. "Agreement between Governments of the Republic of Uzbekistan and People's Republic of China on Creation of Uzbek-Chinese Intergovernmental Committee for Cooperation, Beijing" (20II), available in Russian at <http://www.lex.uz/pages/GetAct.aspx?lact_id=19866II>, accessed September 23, 2017 . 
and the PRC Ministry of Science and Technology), cultural and humanitarian cooperation (coordinated by the Uzbek Ministry of Culture and the PRC Ministry of Culture), and cooperation in security-related issues (coordinated by the Uzbek Ministry of Foreign Affairs and the PRC Ministry of Foreign Affairs). ${ }^{26}$

These committees meet to work at least once a year, with the issues to be discussed communicated through the channels of the coordinating institutions well ahead of the meetings. If the needs of Uzbekistan can be met by a Chinese enterprise, the Chinese coordinating agency frequently serves as the communication line to establish the contacts and invite the potential investor from China to discuss the project. Each of these projects is then considered within a subcommittee. When the interests of the sides do not match, they move on to projects that are of greater mutual interest. In this sense, the establishment of the committee and respective subcommittees created a channel of communication and a sort of bargaining table that is open throughout the year on an ad hoc basis. This committee and its subcommittees are also a good way to signal certain policy and priority changes for each country. They help prevent miscommunications at the political level and provide coordination capacity for enterprise activity. Also, to facilitate connections between businesses, several ministries (for instance, the Uzbek Foreign Trade Ministry and the PRC Ministry of Commerce) have signed memoranda to organize producer exhibitions, which have eventually resulted in the visit of small- and medium-sized enterprise representatives from Tianjin to the Jizzakh and Sirdarya free economic areas, and the decision to allocate certain areas in Jizzakh exclusively for entrepreneurs from that region of China (the Tianjin metro area). ${ }^{27}$

However, this coordination capacity is only made possible through a certain degree of structural similarity in the relations between the government and businesses, as these governments still play a much greater role than in countries with Western liberal market economies. And once an agreement is reached, the government of Uzbekistan still exercises significant control over the economic activities of the enterprises, which is problematic for companies from other countries but acceptable to Chinese corporations due to the

26. See the appendices to the agreement cited in the previous note.

27. "Tashkent Hosts Business Forum of Entrepreneurs of Uzbekistan and China," Jahon, July, 22, 2017, <http://www.jahonnews.uz/en/ekonomika/316/36956/>, accessed June 9, 2018. 
similarity of governmental controls in China. On the Uzbek side, there is a separate committee created to ensure the implementation of the agreements created for each partner country. For instance, aside from China, a separate committee was created to ensure the implementation of agreements with the US. ${ }^{28}$ The committee work is stipulated by road maps for cooperation with each country, and the heads of the committees present reports on progress and the relevant directions of the road maps to the president between the 5 th and the Ioth of each month.

As a result of this work, the focus of the May 2017 visit of President Mirziyoyev to China was obviously on the promotion of economic ties between the two countries based on the "Shanghai spirit" bargaining strategy. ${ }^{29}$ Even before this visit, Uzbekistan and China enjoyed a fair level of economic cooperation, as seen in the list of investment projects underway prior to 2017 announced by the Uzbek Ministry of the Economy. ${ }^{30}$ The visit marked the signing of one of the most ambitious packages of agreements, including II intergovernmental agreements, one intermunicipal agreement, and a package of economic contracts worth US\$ 22.8 billion. ${ }^{31} \mathrm{~A}$ total of 76 agreements, memoranda, and protocols were signed during the visit- 35 agreements, 3I memoranda (notes of meetings that focused on particular projects, with the general budget allocation of these projects already decided), and Io protocols (discussions of intent for particular enterprises). ${ }^{32}$ The most significant areas covered were manufacturing, resource-related investments, and infrastructure development.

28. Decree of the President of Uzbekistan, Measures for Further Strengthening of Cooperation with the UN, Its Structures and International Financial institutions as Well as with a Range of Foreign Countries, PP-3293 (2017), <http://www.norma.uz/raznoe/postanovlenie_prezidenta_ respubliki_uzbekistan_ot_27_09_20I7_g_pp-3293>, accessed September 23, 2017.

29. "Shanghai spirit" refers to a norm which connects the issues for cooperation prioritized by both countries without seeking unilateral gains. This norm also implies the importance of mutual sacrifices and compromises for mutual gains.

30. Ministry of Economy of Uzbekistan, "List of Investment Projects 2016," 2016, <https:// mineconomy.uz/ru/node/ro9I $>$, accessed September 23, 2017.

3I. The amount of US\$ 22.8 billion includes both Chinese and Uzbek shares in the deals signed. Thus the pure Chinese contribution/investment in the deals is roughly US\$ Io billion; the rest accounts for the Uzbek side's contribution, including monetary contributions as well as the costs of land and infrastructure development.

32. "Uzbekistan i Kitai Podpisali Ryad dokumentov" [Uzbekistan and China signed a range of documents], Review.uz, May I3, 20I7, <http://www.review.uz/novosti-main/item/II2I4-uzbekistani-kitaj-podpisali-ryad-dokumentov-spisok>, accessed September 23, 2017. 


\section{INFRASTRUCTURE AND RESOURCES DEVELOPMENT}

The largest economic infrastructure-related agreements were those focusing on the joint production of synthetic fuel (US\$ 3.7 billion), investment in Uzbekistan's oil industry (US\$ 2.6 billion), prospective new projects (US\$ 2 billion), cooperation in the construction of energy generation plants (US\$ 679 million), railroad infrastructure development (US\$ 520 million), and Tashkent to Osh (Kyrgyzstan) road construction (US\$220 million). In terms of establishing manufacturing lines in Uzbekistan, agreements were reached on establishing production facilities for cement (US\$ 153 million in Andijan and US\$ Ioo million in Tashkent), textiles (US\$ 200 million), electric appliances (US\$ 39 million), metals (US\$ II5 million), and glass (US\$ 83 million).

One of the most significant infrastructure agreements signed in May 2017 was between Uzbekistan and the PRC on facilitating smooth international road transportation between the two countries, which involves the simplification of procedures and creation of an environment to increase the transportation of goods using land roads (both rail and automobile). This agreement followed all the internal procedures in Uzbekistan and has been confirmed by decree of the president. ${ }^{33}$

The project, which aims to connect China with Uzbekistan through the territory of the Kyrgyz Republic, has also been addressed in relevant signed agreements. It would connect the Uzbek city of Andijan and the Chinese city of Kashgar, via Osh and Irkeshtam in Kyrgyzstan by both rail and motor road. This is the shortest route, and both countries are interested in its construction. ${ }^{34}$ While China has for years been interested in a number of transport corridors to markets in Europe through CA's transport networks, these particular rail and motor roads are of particular interest and importance to Uzbekistan. They would allow Uzbekistan to shorten the

33. Decree of the President of Uzbekistan on Reconfirming the Agreement between Republic of Uzbekistan and People's Republic of China on Facilitating Smooth International Road Transportation, PP-3I43, July 20, 20I7, available in Russian at <http://nrm.uz/contentf? doc=508717_postanovlenie_prezidenta_respubliki_uzbekistan_ot_20_07_20I7_g_n_pp-3143_ ob_utverjdenii_mejdunarodnogo_dogovora\&products=I_vse_zakonodatelstvo_uzbekistana $>$, accessed September 23, 2017.

34. For details, see "Uzbekistan hochet postroit Andijan-Osh-Irkisham-Kashgar" [Uzbekistan wants to build Andijan-Osh-Irkisham-Kashgar], Kloop, September 9, 20I7, <https://kloop.kg/blog/ 2017/o9/og/uzbekistan-hochet-postroit-trassu-andizhan-osh-irkeshtam-kashgar/>, accessed September 23, 2017. 
distance to transport its goods into China by avoiding Kazakh railroads, which take longer and cost more. The new rail and motor roads would let Uzbekistan ship its goods directly, using the shortest route to China through Kyrgyzstan.

In 20I2, Kyrgyzstan drafted its own railroad project. It would cover more areas of Kyrgyzstan and would be $380 \mathrm{~km}$ longer than the current total. For Kyrgyzstan, it would be a chance to develop its own railroad system and connect remote areas that the rail system currently bypasses. However, for both Uzbekistan and China, this would imply a longer transportation time for their cargo and much higher costs for the project in general. The plans suggested by Kyrgyzstan appear to be difficult for China and Uzbekistan to accept. ${ }^{35}$

Both Chinese and Uzbek officials realize that there is certain degree of caution (especially on the Kyrgyz side) with respect to Chinese infrastructure projects, so they require public engagement and awareness. To facilitate public acceptance of this project, the Chinese and Uzbek governments agreed to organize an auto rally along the route of the future railroad, which serves several important goals. First, it aims to promote to the public transportation infrastructure development projects between Chinese and Central Asian counterparts. Second, it is a practical test of the preparedness of areas where railroad construction is planned, to determine any issues in the terrain and to detail the infrastructure-related facilities that must be constructed in this area. In addition to the railroad, the Chinese Railway Tunnel Group, which built the 19-kilometer-long Kamchik Tunnel in Uzbekistan, has committed to construction of a vehicle motorway under the tunnel, naming the project Kamchik 2. ${ }^{36}$

Uzbekistan's exports of mineral and natural resources to China constitute a considerable share of the trade between the countries. According to other agreements concluded in May 2017 during Mirziyoyev's visit to China, contracts identified natural gas (6 billion $\mathrm{m}^{3}$, worth US\$ 734 million), uranium (US\$ 30 million), textiles (US\$ 200 million), leather (US\$2I.3 million), and

35. See e.g. Bruce Pannier, "No Stops in Kyrgyzstan for China-Uzbekistan Railway Line," Radio Free Europe / Radio Liberty, September 3, 2017, <https://www.rferl.org/a/qishloq-ovozi-kyrgyzstanuzbekistan-china-railway/28713485.html>, accessed September 23, 2017.

36. "China to Help Build Second Tunnel at Kamchik Pass," Tashkent Times, May 16, 20I7, $<$ http://www.tashkenttimes.uz/economy/930-china-to-help-build-second-tunnel-at-kamchik-pass>, accessed September 23, 2017. 
agricultural products (US\$ I.6 million) as products to be exported to China by the end of 20I7. Plans have also been articulated for exports of natural gas to reach US\$2.4 billion for the years 2018 to $2020 .{ }^{37}$ Total exports to China are US\$ I.49 billion, while imports are US\$ 2.0 I billion.

There were also discussions of new pipelines to connect natural gasendowed Turkmenistan, Uzbekistan, and Kazakhstan to Chinese consumers to ensure a stable supply. However, no construction plans or financial commitments have yet been achieved due to uncertainties regarding the economic sustainability of the pipelines' operations.

Chinese companies, such as Shengli Oil and Freet Petroleum, represent strategic partners for the government and related corporations in the provision of pipes and other extraction equipment. According to sources aware of the negotiations between the government and Chinese corporations, at least three contracts for the supply of such equipment were signed during Mirziyoyev's visit to Beijing in 2017.

China National Petroleum Corporation secured a co-financing contract from the Bank of China for a project for drilling at the gas condensate field in Bukhara, Uzbekistan by establishing JV New Silk Road Oil and Gas, which was set up by Uzbekneftegaz and China National Oil and Gas Exploration and Development Corporation (a subsidiary of China National Petroleum Corporation). ${ }^{38}$ According to the license granted to the joint venture, it plans to develop the existing wells and drill another I6, with annual production to reach I billion $\mathrm{m}^{3}$ of natural gas and 6,500 tons of condensate. ${ }^{39}$

In terms of the generation of new industries, Uzbekistan concluded an agreement between Uzbekneftegaz and the Chinese Development Bank (worth US\$ 3.7 billion, of which US\$ I.2 billion is to be financed by China) to finance the establishment of a plant to produce synthetic fuel at

37. "Uzbekistan planiruet k 202I godu narastit' export gaza v Kitaj do Io mlrd" [Uzbekistan plans to increase exports of gas to China to Io billion cubic meters until 202I], Interfax News Agency, June 15, 2017, <http://interfax.az/view/705802>, accessed September 23, 20I7; "Uzbekistan nameren narastit postavki gaza v Kitai" [Uzbekistan aims to increase the volume of its gas exports to China], Aziay Plus, June 15, 2017, <https://news.tj/ru/news/tajikistan/economic/201706I5/uzbekistannameren-narastit-postavki-gaza-v-kitai>, accessed September 23, 2017.

38. "Uzbekistan-China JV New Silk Road Oil and Gas Commences Drilling in Bukhara," Tashkent Times, June 15, 20I7, <http://www.tashkenttimes.uz/economy/ror6-uzbekistan-china-jvnew-silk-road-oil-and-gas-commences-drilling-in-bukhara>, accessed September 23, 2017.

39. Ibid. 
Uzbekistan's largest gas refinery complex, Shurtan. ${ }^{40}$ The plant would process 3.6 billion $\mathrm{m}^{3}$ of natural gas into 743,000 tons of synthetic fuel, 3II,OOo tons of aviation fuel, 431,00o tons of naphtha fuel, and 20,900 tons of liquefied gas. ${ }^{41}$ Technological support for the plant is to be provided by South Korea's Hyundai Engineering \& Construction under a license provided by South African Sasol. The technology for turning natural gas into liquefied gas would come from Dutch Haldor Topsoe.

A US\$ 3 billion agreement between the Chinese Ministry of Commerce and Uzbekgidro stipulates the modernization of approximately 300 water pump stations to improve the efficiency of Uzbekistan's hydroelectricity sector. ${ }^{42}$ Uzbekistan developed and approved the strategy for hydro-energy development in November 2015 and aims to invest US\$ 889.4 million in the sector between 2016 and 2020. The modernization of is hydroelectric stations is planned, to allow the generation of 5.25 billion kilowatts of energy. This governmental program was essential in defining this area as a high priority in relations with China.

Modernization of energy generation in Uzbekistan has also been prioritized in negotiations. In particular, China Railway Tunnel Group and China Coal Technology \& Engineering Group began the modernization of a plant to achieve extraction of 900,000 tons of coal per year, with investment of US\$ 94.5 million. ${ }^{43}$ Non-traditional sustainable sources such as biomass generation have also been the subject of agreements. Uzbekneftegaz, AKB Agrobank (also Uzbek), and China's Poly International Holding signed a memorandum of cooperation to set up the production of modern biogas plants worth US\$ Io million and to assist in the modernization of eight domestic enterprises, including the JSC Oil and Gas and Chemical

40. For details, see George Voloshin, "Central Asia Ready to Follow China's Lead Despite Russian Ties," Eurasia Daily Monitor I4:7I (2017), <https://jamestown.org/program/central-asiaready-follow-chinas-lead-despite-russian-ties/>, accessed September 23, 20I7; "Uzbekistan: President's China Trip Yields Giant Rewards," Eurasianet, May I8, 20I7, <https://eurasianet.org/s/ uzbekistan-presidents-china-trip-yields-giant-rewards>, accessed June 9, 2018.

4I. "Uzbekistan i Kitai podpisali soglazhenij na summu bolee 20 mlrd" [Uzbekistna and China signed agreements for more than 20 billion], Review.uz, May I4, 2017, <http://www.review.uz/ novosti-main/item/II2I7-uzbekistan-i-kitaj-podpisali-soglashenij-na-summu-bolee-2O-mlrd>, accessed September 23, 2017 .

42. Ibid.

43. "Startovala modernizatsiya predpriyatiya 'Shargunkomir" [The modernization of 'Shargunkomir' has started], Gazeta, September 29, 20I7, <https:/www.gazeta.uz/ru/20I7/og/o7/coal/>, accessed September 23, 2017. 
Engineering Plant, in line with the governmental Program of Measures to Increase Biogas Plants in Uzbekistan for 20I7-19. ${ }^{44}$ Last but not least, solid waste processing infrastructure is being constructed to improve livelihoods and facilitate better waste utilization in old and newly constructed housing in Uzbekistan. ${ }^{45}$

\section{MANUFACTURING AND EXPORT INDUSTRIES}

As described above, the new administration in Uzbekistan has defined certain areas where China's economic presence and technology are desired and advantageous. In line with the goals of the development strategy, the first such area is the establishment of small and medium-sized manufacturing plants to not only supplement imported products but also, importantly, produce goods that can compete in Central Asian markets.

In particular, Uzbekistan intends to establish long-term cooperation with the Chinese Aerospace Science and Industry Corporation (CASIC) for the supply of scanning equipment (for border control services, customs, airports, and rail infrastructure), the introduction of urban security systems ("smart city"), the protection of large facilities and the border, the development and introduction of an industrial Internet, joint production of a wide range of pharmaceuticals in Uzbekistan, and the participation of CASIC in the development of infrastructure for the Central Military Clinical Hospital of the Ministry of Defense. This latter project includes creating a turnkey multidisciplinary medical and diagnostic building and equipping it with modern medical equipment, as well as producing oil and gas equipment. ${ }^{46}$

To respond to the increasing demand for construction materials, the Uzbek government intends to facilitate the development of a cement plant (with Zhejiang Shangfeng Building Materials, at a cost of US\$ 203.9 million $)^{47}$ and

44. "Program for Increased Use of Biogas in Farms Adopted in Uzbekistan," Tashkent Times, June 19, 20I7, <http://www.tashkenttimes.uz/economy/ro6o-program-for-increased-use-of-biogasin-farms-adopted-in-uzbekistan>, accessed September 23, 2017.

45. Beston Machinery Company, "Beston Municipal Solid Waste Plant in Uzbekistan," undated, $<$ http://mswrecyclingplant.com/beston-municipal-solid-waste-plant-uzbekistan/>, accessed September 23, 2017.

46. For details, see "Ministry of Foreign Trade Discuss Cooperation with 'CASIC' Corporation," Uzreport, June I6, 20I7, <http://news.uzreport.uz/news_4_e_I53308.html>, accessed September 23, 2017.

47. "New Cement Plant for US\$204 Million to be Built in Andijan Region," Uzdaily, July 2I, 20I7, <https://uzdaily.com/PYLnM/articles-id-40I76.htm>, accessed July 2I, 2017. 
glass production (with MingYuan Silu, at a cost of US\$ IIo million). ${ }^{48}$ Another joint venture has been established in Gulistan City, focusing on the production of elevators. In the Soviet era, Uzbekistan relied heavily on elevators produced in other republics, namely Azerbaijan and Russia. With the collapse of the Soviet Union, the replacement of installed elevators required importing them in great numbers. To fill this gap and respond to the increasing need for elevators in the booming construction business in Uzbekistan, the government sought China's assistance in facilitating the production of elevators in Uzbekistan. As a result, a joint venture for the production of elevators (Modern Lift Systems) has been established in the Syrdarya Region of Uzbekistan, funded by Chinese investors and using Chinese technology. It produces 300 elevators per year, plus 200 escalators and travolators (moving walkways). Although the joint venture produces elevators for internal consumption, approximately $30 \%$ of its products are to be exported to other regional states. ${ }^{49}$

In terms of memoranda and protocols, some of these have already materialized in production facilities, such as the one for the production of soft and hard toys in Tashkent, based on the Soviet-era toy factory Tashkentigrushka. ${ }^{50}$ As mentioned, Uzbekistan is the most populous country in CA, and $60 \%$ of its 32 million people (2017) are under 25. The population has the highest growth rate in CA, which creates a big market for toys and child-related products. In the Soviet era, Uzbekistan hosted one of the biggest toy factories. But with the collapse of the Soviet Union and aging technology, the plant became unable to meet the needs of the market. The quality of toys imported from other countries, including China, was at the level expected by consumers, motivating the government to seek a solution to this issue. Imports of toys reached US\$2.I million in 20I6, but fell $29 \%$ in 2017 due to increasing local production. As mentioned, $94 \%$ (US\$ 2 million) of the toys imported into Uzbekistan are from China; Russia's share is only 2.I\%

48. "Glass Production Plant to be Considered in Uzbekistan," Uzdaily, September 2I, 20I7, $<$ https://www.uzdaily.com/articles-id-37934.htm>, accessed September 23, 2017.

49. "Proizvodtsvo liftov zapuscheno v Uzbekistane" [Production of elevators launched in Uzbekistan], Gazeta, September 29, 20I7, <https://www.gazeta.uz/ru/20I7/o9/29/lifts/>, accessed September 23, 2017.

50. "O merakh po organizatsii sovremennogo proizvodstva detskih prinadlezhnostei i igrushek v gorode Tashkente" [Decree of the President of the Republic of Uzbekistan on measures for organization of production of children's accessories and toys in the city of Tashkent], PP-3II5, July 6, 2017 . 
(US\$ 43,00o), with the remaining $0.8 \%$ (US\$ 16,000 ) from Lithuania. ${ }^{51}$ The new factory (jointly established with Shandong Sanhe Toy) cost an estimated US\$ 23 million, makes 700 kinds of plastic, soft, electronic, and mechanical toys, and provides 950 jobs in Tashkent. ${ }^{52}$

The majority of these projects attempt to establish production- and infrastructure-related facilities to enable Uzbekistan to produce goods not only for its large (but still limited) internal consumption but also, importantly, for export. The toy factory aims to produce seven million individual toys annually, of which $80 \%$ are meant for export to other countries of CA, Russia, Afghanistan, and beyond. Similar plants are also planned in conjunction with other Chinese producers (such as Zhejiang Jiyou) in the Jizakh free economic area. ${ }^{53}$

Similar protocols for intentions to establish production plants for ceramics with Peng Yu Special Ceramics and Zhongguo Jingdezhen Porcelain, and a porcelain production plant with Ru Hong, have been signed. ${ }^{54}$ Although the documents signed with representatives of these companies were protocols of intention without firm commitments, in June and July 2017 the representatives visited possible sites for plant construction and discussed conditions with various ministries, such as the Ministry of Foreign Trade, the Foreign Investments Agency, and the State Committee for Competition Controls.

Among the agreements signed between the two countries, Sun Paper Industry and China National Complete Plant Import \& Export signed a protocol of intentions with the government to create a cluster for the production of high-quality paper in the Angren free economic zone. ${ }^{55}$ Uzbekistan currently does not have such facilities and needs to import much of the

5I. "Uzbekistan and China Will Create Production of Joint Venture on Production of Toys," Gazeta, August 2, 20I7, <https://www.gazeta.uz/ru/20I7/o8/o2/toys/>, accessed August 4, 2017.

52. For details, see "Klaster po vypusku igrushek stoimost'yu $23 \mathrm{mln}$ pyavitsya v Tashkente" [Cluster producing toys costing $23 \mathrm{mln}$ will appear in Tashkent], Gazeta.uz, September 13, 20I7, $<$ https://www.gazeta.uz/ru/20I7/o9/r3/cluster/>, accessed September I4, 2017.

53. "Zhejiang Jiyou Industrial Co. Ltd. May Create Capacities for Toy Production in Uzbekistan," Uzdaily.uz, July 3, 2017, <https://www.uzdaily.com/articles-id-39970.htm>, accessed September 23, 2017.

54. "FEZ 'Angren' May Become the Largest Producer of Porcelain in the Country," UzbekistanToday, July 3, 20I7, <http://ut.uz/en/business/fez-angren-may-become-the-largest-producer-ofporcelain-in-the-country/>, accessed September 23, 2017.

55. "COMPLANT planiruet organizovat' proizvodstvo bumagi v Uzbekistan" [COMPLANT plans to organize production of paper in Uzbekistan], Obschestvo Druzhby Kitaj-Uzbekistan, September I8, 2017, <http://china-uz-friendship.com/?p=I2945>, accessed September 23, 2017. 
high-quality paper used in office paperwork, as well as for wrapping and shipping the goods produced in various plants. ${ }^{56}$ Delegations from these companies visited Uzbekistan in September 2017 to evaluate the needs and coordinate the supplies of equipment with local counterparts.

In terms of the export of Uzbek-made products, the agreements signed during the May 2017 visit of President Mirziyoyev included textile exports (US\$ 300 million), leather (US\$ 60 million), and agricultural products (US\$ I.6 million) in 20I7-I8. These contracts are in active implementation, and the majority are being implemented. Also, cotton-processing and textile mills have been planned, with Chinese participation, in Qashqadaryo for 20I7-19. Seven textile mills are under construction in Qashqadaryo, and its overall cotton processing capacity will account for Io\% of the annual cotton output of the Qashqadaryo Region. ${ }^{57}$ The Litai project aims to create 500 jobs, using textile machinery from the Saurer Group, and to produce 22,000 tons of high-level cotton yarn annually, $80 \%$ for export. ${ }^{58}$ Wenzhou Jinsheng Trading announced that it will initiate seven investment projects in the Jizzakh economic zone, investing US\$ 40 million in reprocessing local resources and producing leather goods and metal products, one-third to be exported out of Uzbekistan. ${ }^{59}$

\section{CONCLUSION}

A few conclusions can be drawn from the analysis of cooperation between Uzbekistan and China in this article. Uzbekistan's relations with China in the year after the death of President Karimov and of the opening up of Uzbekistan to the international community demonstrate that the master narrative overestimates Chinese domination in both agenda-setting and project implementation in areas of economic cooperation. Although both

56. "V Uzbekistane budet sozdano SP po proizvodstvu bumagi" [Uzbekistan will create joint venture on production of paper], Uzreport, September I8, 20I7, <https://uzreport.news/economy/ v-uzbekistane-budet-sozdano-sp-po-proizvodstvu-bumajnoy-produktsii>, accessed September 23, 2017.

57. "Uzbekistan President Visits Litai Silk Road Park," Jinsheng, March 4, 20I7, <http://www .jinshengroup.com/en/stations/53266Ib6ob/index.php/5327edgboa?id=I6I $>$, accessed September 23, 2017.

58. Ibid.

59. "Kitaj pomozhet realizovat v SEZ 'Jizzakh' proekty stoimost'yu \$40 millionov" [China will help implement projects worth 40 million in Jizzakh SEZ], Sputnik, August II, 20I7, <http://ru .sputniknews-uz.com/economy/20I708II/60I4975/kitai-sez-djizak-proekti.html>, accessed September 23, 2017 . 
China and Uzbekistan are attempting to shape their new foreign policies in a changing international environment, most of the projects detailed in this article focus on areas that are defined as highly important for either Uzbekistan or China. It does not appear that China is using its economic power to pressure smaller Uzbekistan. There are several factors that allow Uzbekistan to maintain its relations with China without sacrificing its own interests. First, in case one or more projects collapse, Uzbekistan has been diversiying its strategic partners and building ties with alternative countries. This provides a diverse selection of partners for particular developmental goals. It also keeps some pressure on China not to dominate the cooperation agenda if it sees value in engaging Uzbekistan.

Second, Sino-Uzbek relations demonstrate that neither China's nor Uzbekistan's foreign policy behavior has a static structure or goal. Analysts and observers tend to emphasize the dominating tendencies of Chinese economic expansion (by emphasizing energy resources) or its agenda for negotiations. The projects described in this article demonstrate that a majority of the cooperative initiatives are products of social construction between the main actors and their negotiations. The funded and facilitated projects in Uzbekistan do not represent a "one-way street" of Chinese expansionist policy.

Third, the outcomes of this cooperation are greatly influenced by the respective government bureaucracies and their facilitation of interstate cooperation. In countries where the governments play similar proactive roles in defining economic policies, the role of bureaucracies is instrumental in ensuring productive cooperation. In Uzbekistan's policy in respect to China, its strategy for development and its overall goals of diversifying the economy and orienting industry toward exports serve as markers for the Uzbek bureaucracy when deciding priorities. Those guidelines and bureaucratic procedures of agenda-setting assist in streamlining the agenda of cooperation with China in a desirable direction, not only for Chinese interests but also for the cooperating partner, in this case Uzbekistan. 